\title{
Analisis Kinerja Keuangan Perusahaan Dagang PT. Ace Hardware Indonesia, Tbk Di Bursa Efek Indonesia Periode 2014 - 2019
}

\author{
Abd. Halim ${ }^{1}$, Indria Mayesti ${ }^{2}$, Rika Neldawaty ${ }^{3}$, Sri Wahyuni $^{4}$ \\ ${ }^{2}$ BPSDM Provinsi Jambi \\ 1,3,4 Universitas Muhammadiyah Jambi \\ Email : Indriamayesti11@gmail.com, Abdh0074@gmail.com, Rikaneldawaty1079@gmail.com,wsriii955@gmail.com
}

\begin{abstract}
Abstrak_ Tujuan dari penelitian ini yaitu menjelaskan Analisis Kinerja Keuangan Peruhsaaan (Studi Kasus PT. ACE HARDWARE Indonesia, Tbk) penelitian ini bertujuan untuk mengetahi Bagaimana kinerja keuangan pada perusahaan PT. Ace Hardware Indonesia di Bursa Efek Indonesia dilihat rasio Likuiditas pada periode 2014-2019? 2) Bagaimana kinerja keuangan pada perusahaan PT. Ace Hardware Indonesia di Bursa Efek Indonesia dilihat rasio Solvabilitas pada periode 2014-2019? 3) Bagaimana kinerja keuangan pada perusahaan PT. Ace Hardware Indonesia di Bursa Efek Indonesia dilihat rasio Rentabilitas pada periode 2014-2019? Hasil penelitian berdasarkan hasil Rasio Likuiditas terdiri dari Current ratio dan Quick ratio secara keseluruhan rata-rata pada perusahaan PT. Ace Hardware Indonesia periode 2014-2019 menunjukkan kondisi perusahaan yang likuid dimana likuiditas digunakan secara maksimal oleh perusahaan untuk menghasilkan pendapatan. Rasio Solvabilitas terdiri dari Debt to Asset Ratio dan Debt to Equity secara keseluruhan rata-rata pada perusahaan PT. Ace Hardware Indonesia menunjukkan kondisi perusahaan yang solvabel.
\end{abstract}

Kata Kunci: Kinerja, Rentabilitas, Solvabilitas dan Rentabilitas

Abstract_The purpose of this study is to explain the Analysis of Corporate Financial Performance (Case Study PT. ACE HARDWARE Indonesia, Tbk). This study aims to determine how the financial performance of the company PT. As seen from the Liquidity ratio of Ace Hardware Indonesia in the Indonesia Stock Exchange in the 2014-2019 period? 2) How is the financial performance of PT. Seeing the solvency ratio for Ace Hardware Indonesia on the Indonesia Stock Exchange in the 2014-2019 period? 3) How is the financial performance of PT. Ace Hardware Indonesia on the Indonesia Stock Exchange seen in the Rentability Ratio in the 2014-2019 period? The results of the study are based on the results of the liquidity ratio consisting of the current ratio and the quick ratio as a whole in the company PT. Ace Hardware Indonesia for the 2014-2019 period shows a liquid company condition where liquidity is used maximally by the company to generate revenue. Solvency ratios consist of Debt to Asset Ratio and Debt to Equity as a whole in the company PT. Ace Hardware Indonesia shows a solvable company condition. Keywords: Performance, Rentability, Solvency and Profitability

Keywords: Performance, Rentability, Solvency and Rentability

\section{PENDAHULUAN}

PT. Ace Hardware Indonesia tbk (AHI) sebagai salah satu perusahaan yang menjual perlengkapan rumah \& gaya hidup terlengkap, yang juga mengelola beberapa cabang. Perusahaan ini adalah usaha yang berdasarkan ketelitian, kepercayaan, tanggung jawab, dan resiko yang besar. Tantangan yang dihadapi untuk meningkatkan keuntungan dirasakan semakin berat akibat persaingan yang semakin ketat. Sebagai perintis dalam bisnis home improvement dan lifestyle, perseroan dikenal luas dalam menyediakan berbagai macam produk berkualitas. Dengan lebih dari 80.000 produk, Ace Hardware indonesia mengelompokan produk-produk dalam tiga segmen yaitu home improvement, lifestyle, dan toys. Pertumbuhan gerai baru cepat menunjukan adanya peningkatan permintaan yang signifikan atas produkproduk home improvement dan lifestyle yang berkualitas. Sebagai konsekuensi dari program ekspansi yang agresif, terjadi penurunan penjualan dibebarapa wilayah. Perseroan telah menginvestasi modal kerja lebih tinggi lagi, terutama pada persediaan. Alasan utamanya karena seiring dengan pembukaan lebih banyak gerai diluar Jakarta (dalam Jurnal Kurniati Ningsih, Abdul Rachim, dan Rudy Syafariansyah, 2019). Rumusan Masalah 1)
Bagaimana kinerja keuangan pada perusahaan PT. Ace Hardware Indonesia di Bursa Efek Indonesia dilihat rasio Likuiditas pada periode 2014-2019? 2) Bagaimana kinerja keuangan pada perusahaan PT. Ace Hardware Indonesia di Bursa Efek Indonesia dilihat rasio Solvabilitas pada periode 2014-2019? 3) Bagaimana kinerja keuangan pada perusahaan PT. Ace Hardware Indonesia di Bursa Efek Indonesia dilihat rasio Rentabilitas pada periode 2014-2019?

Kinerja keuangan merupakan kondisi yang mencerminkan keadaan keuangan suatu perusahaan berdasarkan sasaran, standar dan kriteria yang telah ditetapkan. Kinerja keuangan merupakan gambaran dari pencapaian keberhasilan perusahaan dapat diartikan sebagai hasil yang telah dicapai atas berbagai aktivitas yang telah dilakukan. Selanjutnya Harmono (2009) menyatakan bahwa kinerja keuangan 00umumnya diukur berdasarkan penghasilan bersih (laba) atau sebagai dasar bagi ukuran yang lain seperti imbalan investasi (return on investment) atau penghasilan persaham (earnings per share). Laporan keuangan menurut Fahmi (2012) dalam Ayu Nur Indriani, (2017) merupakan suatu informasi yang menggambarkan kondisi suatu perusahaan, dimana selanjutnya akan 
menjadi suatu informasi yang menggambarkan tentang kinerja suatu perusahaan. Sedangkan menurut Sadeli ( 2002) laporan keuangan ialah hasil dari proses akuntansi dan merupakan informasi historis. Akuntansi adalah proses pengidentifikasian, mengukur dan melaporkan informasi ekonomi untuk membuat pertimbangan dan mengambil keputusan yang tepat bagi pemakai informasi tersebut. Rasio Likuiditas (Liquidity Ratio) Rasio likuiditas merupakan rasio yang digunakan untuk mengukur kemampuan perusahaan untuk memenuhi kewajiban jangka pendek dan membandingkan kewajiban jangka pendek dengan sumber daya jangka pendek (atau lancar) yang tersedia untuk memenuhi kewajiban tersebut. rasio solvabilitas diperlukan sebagai dasar pertimbangan dalam memutuskan antara penggunaan dana dari pinjaman atau penggunaan dana dari modal sebagai alternatif sumber pembiayaan aset perusahaan. Sebagaimana yang telah dijelaskan sebelumnya bahwa perhitungan ini perlu dilakukan secara cermat mengingat bahwa masing-masing jenis pembiayaan tersebut memiliki beberapa kelebihan maupun kekurangan. Sama halnya denga rasio likuiditas, rasio solvabilita juga diperlukan kepentingan analisis kredit atau analisis rasio keuangan.

\section{METODE}

Teknik analisis data pada penelitian kuantitatif menggunakan statistik. Dalam penelitian ini analisis data akan menggunakan teknik analisis statistik deskriptif. Menurut Ghozali (2013) dalam Jurnal Erni Puji Astutik, Retnosari, Ayunda Putri Nilasari, Dinar Melani Hutajulu (2019) Statistik deskriptif memberikan gambaran atau deskripsi suatu data yang dilihat dari nilai rata-rata (mean), standar deviasi, varian, maksimum, minimum, sum, range, kurtosis, dan skewness.

Untuk memecahkan masalah dalam penelitian ini peneliti menggunakan teknik statistik deskriptifdengan menggunakan analisis rasio sebagai berikut :

1. Rasio likuiditas dibagi menjadi 2 yaitu :

Ratio Lancar (Current Ratio)dengan rumus :

Rasio Lancar $=\frac{\text { Aktiva lancar }}{\text { Hutang Lancar }}$

Ratio Cepat (Quick Ratio) denga rumus :

Rasio Cepat $=\frac{\text { Aktiva lancar }- \text { Persediaan }}{\text { Hutang Lancar }}$
2. Rasio Solvabilitas dibagi menjadi 2 yaitu:

Debt to Asset Ratio dengan rumus :

Debt To Aset $=\frac{\text { Total Hutang }}{\text { Total Aset }}$

Debt to Equity Ratio dengan rumus :

Debt To Equity Ratio $=\frac{\text { Total Hutang }}{\text { Total Ekuitas }}$

3. Rasio Rentabilitas dibagi menjadi 2 yaitu :

Net Profit Margin(Margin Laba Bersih)rumus :

Net Profit Margin $=\frac{\text { Laba Bersih }}{\text { Penjualan Bersih }}$

Return on Asset (ROA) rumus :

ROA $=\frac{\text { Laba Bersih setelah Pajak }}{\text { Total Asset }}$

Return on Equity (ROE) rumus :

ROE $=\frac{\text { Laba setelah Pajak }}{\text { Modal Sendiri }}$

\section{HASIL DAN PEMBAHASAN}

Permasalahan yang dihadapi PT. Ace Hardware Indonesia,Tbk, yaitu untuk mengetahui adanya kenaikan dan penurunan kinerja perusahaan dengan membandingkan laporan keuangan dari periode tahun 2014-2019. Laporan keuangan perusahaan merupakan salah satu sumber informasi yang penting dalam mengambil suatu keputusan. Tetapi suatu laporan keuangan akan kurang mempunyai arti apabila tidak dapat dianalisis. Analisis rasio keuangan adalah salah satu alat untuk menganalisis laporan keuangan suatu perusahaan dan untuk menegtahui kondisi keuangan suatu perusahaan serta kinerja perusahaan ditinjau dari keuangannya. Bagi para investor, analisis rasio keuangan merupakan indikator yang penting untuk mengetahui kesehatan perusahaan dari posisi relatif. Dengan mengetahui kesehatan perusahaan maka para investor dapat melakukan transaksi pembelian saham untuk perusahaan yang sehat dan mempunyai prospek keuntungan di masa mendatang. Dengan demikian investor dapat mencapai keuntungan yang optimal baik berupa deviden maupun capitalgain.

Berdasarkan penjelasan diatas, maka untuk mnganalisis rasio keuangan sebagai alat untuk menilai kinerja keungan perusahaan pada periode2014-2019 dibursa efek indonesia. Dimana dalam penelitian ini terdiri dari tiga variabel yaitu rasio lukiditas, solvabilitas dan rentabilitas.

Tabel 1. Analisis Rasio Keuangan

\begin{tabular}{|c|c|c|c|c|c|c|c|}
\hline \multirow{2}{*}{ Keterangan } & \multicolumn{6}{|c|}{ Tahun } & \multirow{2}{*}{ Mean } \\
\hline & 2014 & 2015 & 2016 & 2017 & 2018 & 2019 & \\
\hline Current Ratio & 5,088 & 5,448 & 7,261 & 7,022 & 6,491 & 8,076 & 6,564 \\
\hline Quick Ratio & 2,051 & 1,598 & 3,169 & 3,155 & 3,068 & 3,403 & 2,740 \\
\hline Debt to Asset Ratio & 0,198 & 0,196 & 0,182 & 0,207 & 0,204 & 0,198 & 0,197 \\
\hline Debt to Equity Ratio & 0,247 & 0,244 & 0,223 & 0,261 & 0,256 & 0,248 & 0,246 \\
\hline Net Profit Margin & 0,120 & 0,112 & 0,143 & 0,131 & 0,134 & 0,127 & 0,127 \\
\hline Return on Asset & 0,186 & 0,126 & 0,189 & 0,176 & 0,183 & 0,175 & 0,172 \\
\hline Return on Equity & 0,232 & 0,157 & 0,231 & 0,222 & 0,230 & 0,218 & 0,215 \\
\hline
\end{tabular}

Sumber : Data diolah 2020 
Berdasarkan hasil analisis laporan keuangan pada PT. Ace Hardware Indonesia diketahui bahwa current ratio menunjukkan kemampuan perusahaan dalam mengembalikan utang jangka pendeknya dengan menggunakan aktiva lancarnya. Pada tabel diatas untuk CR periode 2014-2019 mengalami fluktuatif setiap tahunnya dan rasio yang dihasilkan menunjukkan angka diatas rata-rata perkembangan yaitu sebesar 6,564 . Untuk tahun 2014 besar CR yaitu 5,088 dan 2015 sebesar 5,448. Untuk tahun 2016-2019 nilai CR sebesar 7,261(2016), 7,022(2017), 6,491(2018), 8,076(2019) dan untuk nilai minimum CR sebesar 5,088 pada tahun 2014 dan nilai maksimal sebesar 8,076 pada tahun 2019 . Quick ratio (rasio cepat) menunjukkan kemampuan perusahaan memenuhi, membayar kewajiban atau utang lancar (utang jangka pendek) dengan aktiva lancar tanpa memperhitungkan nilai persedian. Pada tabel diatas untuk QR periode 2014-2019 mengalami fluktuatif setiap tahunnya dan rasio yang dihasilkan menunjukkan angka diatas rata-rata perkembangan yaitu sebesar 2,740. Untuk tahun 2014 besar QR yaitu 2,051 dan 2015 sebesar 1,598. Untuk tahun 2016-2019 nilai CR sebesar 3,169(2016), 3,155(2017), 3,068(2018), 3,403(2019) dan untuk nilai minimum CR sebesar 1,598 pada tahun 2015 dan nilai maksimal sebesar 3,403 pada tahun 2019. Debt to asset ratio (DAR) adalah seberapa besar aktiva perusahaan dibiayai oleh utang atau seberapa besar utang perusahaan berpengaruh terhadap pengelola aktiva. Pada tabel diatas untuk DAR pada tahun 2014 sebesar 0,198 dan pada tahun 2015 sebesar 0,196 untuk tahun 20162019 DAR sebesar 0,182(2016), 0,207(2017), 0,207(2018), 0,198(2019) dan untuk nilai minimum DAR sebesar 0,182 pada tahun 2016 dan nilai maksimal sebesar 0,207 pada tahun 2017. Dengan nilai rata-rata DAR sebesar 0,197. Debt to equity ratio (DER) adalah rasio yang digunakan untuk menilai utang dengan ekuitas. Dengan kata lain, rasio ini berfungsi untuk mengetahui setiap rupiah modal sendiri yang dijadikan untuk jaminan utang. Rasio yang dihasilkan menunjukkan angka diatas rata-rata perkembangan yaitu sebesar 0,246. Pada tabel diatas untuk DER pada tahun 2014 sebesar 0,247 dan pada tahun 2015 sebesar 0,244. Untuk tahun 2016-2019 DER sebesar 0,223(2016), 0,261(2017), 0,256(2018), 0,248(2019) dan untuk nilai minimum DER sebesar 0,223 pada tahun 2016 dan nilai maksimal sebesar 0,261 pada tahun 2017. Net profit margin (margin laba bersih) adalah menghitung sejauh mana kemampuan perusahaan menghasilkan laba bersih pada tingkat penjualan tertentu. Pada tabel diatas untuk rasio NPM pada tahun 2014 sebesar 0,120 dan pada tahun 2015 sebesar 0,112. Untuk tahun 2016-2019 NPM sebesar 0,143(2016), 0,131(2017), 0,134(2018) $0,127(2019)$ dan untuk nilai minimum sebesar 0,112 pada tahun 2015 dan nilai maksimal sebesar 0,143 pada tahun 2016. Dengan nilai rata-rata NPM sebesar 0,127. Return on asset (ROA) adalah Rasio ini menunjukkan kemampuan aktiva perusahaan memperoleh laba dari operasi perusahaan. Asset yang digunakan dalam mengukur kemampuan memperoleh laba adalah asset operasional. Pada tabel diatas untuk ROA periode 2014 2019 mengalami fluktuatif setiap tahunnya dan rasio yang dihasilkan menunjukkan angka diatas rata-rata perkembangan yaitu sebesar 0,172. Pada tabel diatas untuk ROA tahun 2014 sebesar 0,186 dan pada tahun 2015 sebesar 0,126. Untuk tahun 2016-2019 ROA sebesar 0,189(2016), 0,176(2017), 0,183(2018), 0,175 (2019) dan untuk nilai minimum ROA sebesar 0,126 pada tahun 2015 dan nilai maksimal sebesar 0,189 pada tahun 2016. Return on equity (ROE) adalah rasio yang memperlihatkan sejauh manakah perusahaan mengelola modal sendiri (networth) secara efektif mengukur tingkat keuntungan dari inverstasi yang telah dilakukan pemilik modal sendiri atau pemegang saham. Pada tabel diatas untuk ROE periode 2014-2019 mengalami fluktuatif setiap tahunnya dan rasio yang dihasilkan menunjukkan angka diatas rata-rata perkembangan yaitu sebesar 0,215. Pada tabel diatas untuk ROE tahun 2014 sebesar 0,232 dan pada tahun 2015 sebesar 0,157 dan untuk tahun 2016-2019 ROE sebesar 0,231(2016), 0,222(2017), 0,230(2018), 0,218(2019) dan untuk nilai minimum ROE sebesar 0,157 pada tahun 2015 dan nilai maksimal sebesar 0,232 pada tahun 2014.

Likuiditas Berdasarkan hasil analisis deskriptif diketahui bahwa variable CR perusahaan PT. Ace Hardware Indonesia periode 2014-2019 yang memiliki nilai yang paling rendah sebesar 5,088 pada tahun 2014 dan yang memiliki nilai yang paling tinggi sebesar 8,076 pada tahun 2019 dengan nilai rata-rata sebesar 6,564 artinya setiap 1 rupiah hutang lancar dapat dijamin oleh aktiva lancer sebesar 6,564. Untuk variabel QR perusahaan PT. Ace Hardware Indonesia periode 20142019 memiliki nilai yang paling rendah sebesar 1,598 pada tahun2015 dan yang memiliki nilai yang paling tinggi sebesar 3,403 pada tahun 2019 dengan nilai ratarata 2,740 artinya setiap 1 rupiah total hutang lancar dapat dijamin oleh aktiva yang lebih likuid tanpa persedian sebesar 2,740.

Solvabilitas Berdasarkan hasil analisis deskriptif diketahui bahwa variable DAR perusahaan PT. Ace Hardware Indonesia periode 2014-2019 yang memiliki nilai yang paling rendah sebesar 0,182 pada tahun 2016 dan yang memiliki nilai yang paling tinggi sebesar 0,207 pada tahun 2017 dengan nilai rata-rata 0,197 artinya setiap 1 rupiah total hutang dapat dijamin oleh total aktiva sebesar 0,197. Untuk variable DER perusahaan PT. Ace Hardware Indonesia periode 2014-2019 memiliki nilai yang paling rendah sebesar 0,223 pada tahun 2016 dan yang memiliki nilai yang paling tinggi 0,248 pada tahun 2019 dengan nilai rata-rata sebesar 0,246 artinya rasio setiap 1 rupiah total hutang dapat dijamin oleh modal sendiri sebesar 0,246. 
Rentabilitas Berdasarkan hasil analisis deskriptif diketahui bahwa variable NPM perusahaan PT. Ace Hardware Indonesia periode 2014-2019 yang memiliki nilai yang paling rendah sebesar 0,112 pada tahun 2015 dan nilai yang paling tinggi sebesar 0,143 pada tahun 2016 dengan nilai rata-rata sebesar 0,127 berarti bahwa laba bersih sesudah pajak yang dicapai adalah sebesar 0,127 dari volume penjualan. Untuk variable ROA perusahaan PT. Ace Hardware Indonesia periode 20142019 memiliki nilai yang paling rendah sebesar 0,126 pada tahun 2015 dan yang memiliki nilai yang paling tinggi sebesar 0,189 pada tahun 2016 dengan nilai ratarata 0,172. Dan untuk variable ROE perusahaan PT. Ace Hardware Indonesia periode 2014-2019 memiliki nilai yang paling rendah sebesar 0,157 pada tahun 2015 dan yang memiliki nilai yang paling tinggi sebesar 0,232 pada tahun 2014 dengan nilai rata-rata sebesar 0,215 artinya rasio sebesar 0,215 menunjukan bahwa tingkat penghasilan yang diperoleh pemilik perusahaan atas modal yang diinvestasikan adalah sebesar 0,215.

\section{SIMPULAN}

Rasio Likuiditas terdiri dari Current ratio dan Quick ratio secara keseluruhan rata-rata pada perusahaan PT. Ace Hardware Indonesia periode 2014-2019 menunjukkan kondisi perusahaan yang likuid dimana likuiditas digunakan secara maksimal oleh perusahaan untuk menghasilkan pendapatan. Rasio Solvabilitas terdiri dari Debt to Asset Ratio dan Debt to Equity secara keseluruhan rata-rata pada perusahaan PT. Ace Hardware Indonesia menunjukkan kondisi perusahaan yang solvabel. Rasio Rentabilitas terdiri dari Net Propit Margin, Return on Asset, dan Return on Equity secara keseluruhan rata-rata pada perusahaan menunjukkan bahwa dengan kondisi likuiditas dan solvabilitas yang ada mampu memberikan return diatas rata-rata perkembangan. Maka dari itu kinerja keuangan PT. Ace Hardware Indonesia dalam keadaan baik ditinjau dari rasio rentabilitas.

\section{DAFTAR PUSTAKA}

Anwar K.R, 2011. Analisis Kinerja Keuangan pada PT. Mega Indah Sari Makassar. Skripsi. Fakultas Ekonomi. Universitas Hasanuddin Makassar, Makassar.

Astutik E.P, Retnosari, Nilasari A.P, Hutajulu D.M. Analisis Pengaruh Rasio Likuiditas, Solvabilitas dan Profitabiltas Terhadap Kinerja Keuangan Perusahaan Manufaktur. Prosiding Seminar Nasional dan Call For Papers. Fakultas Ekonomi Universitas Tidar, 2019, Hal 107.

Ermawati Emmy. Analisis Kinerja Keuangan Klinik Husada Mulia Kabupaten Lumajang. Jurnal Ilmiah Ilmu Akuntansi, Keuangan dan Pajak Vol. 2 No. 1 Januari 2018, Hal 28.

Fitra. H, Henri. A, Sama. T, Erly. M. Analisis Kinerja Keuangan Perusahaan Sektor Pertambangan yang
Terdaftar di Jakarta Islamic Index dengan Menggunakan Economic Value Added. Jurnal Wahana Riset Akuntansi, Vol.7, No. 2, Oktober 2019, Hal 3.

Febrianty, Wulandari. Kinerja Keuangan Perusahaan Property dan Rel Estate di BEI Selama Periode 2012-2016 yang Termasuk di Indeks LQ45 (Studi Perushaan yang Termasuk Pemeringkatan Indeks LQ45 Periode Februari 2017-Juli 2017). Jurnal Manajemen dan Bisnis Sriwijaya, Vol.15, No.1,2017, Hal 5.

Fandy Giyono Saputro, 2014. Analisis Kinerja Keuangan Perusahaan BUMN Bidang Konstruksi yang Terdaftar di Bursa Efek Indonesia Periode 2010-2013. Skripsi. Fakultas Ekonomi. Universitas Negeri Yogyakarta.

Herviani Vina, Febriansyah Angky. Tinjauan atas Proses Penyusunan Laporan Keuangan pada Young Enterpreneur Academy Indonesia Bandung. Jurnal Riset Akuntansi, Vol VIII, No.2, Oktober 2016, Hal 23.

Hery. 2014. Analisis Kinerja Manajemen. PT. Grasindo, Jakarta.

Indriani A.N, 2017. Analisis Kinerja Keuangan Perusahaan yang Terdaftar diBursa Efek Indonesia (BEI) Sebelum dan Sesudah Akuisisi. Skripsi. Fakultas Ekonomi. Universitas Negeri Yogyakarta, Yogyakarta.

Kurniawan Jhoni, 2017. Analisis Kinerja Keuangan Perusahaan Food and Beverage yang Terdaftar Di Bursa Efek Indonesia Periode 2011-2015. Skripsi. Fakultas Ekonomi dan Bisnis Islam. Institut Agama Islam Negeri Surakarta, Surakarta.

Kaunang Swita Angelia. Analisis Kinerja Keuangan Perusahaan pada PT.Cipta Daya Nusantara Manado. Jurnal EMBA Vol.1, No.4, Desember 2013, Hal 3.

Mandasari Diana, 2017. Analisis Laporan Keuangan Dalam Mengukur Kinerja Keuanga Pada CV. Awijaya Palembang. Skripsi. Fakultas Ekonomi dan Bisnis. Universitas Muhammadiyah Palembang.

Muhammad Fathul Muin, 2015. Analisis Kinerja Keuangan pada PT. Aneka Tambang (Persero),Tbk UBP Nikel Sulawesi Tenggara Di Pomalaa Tahun 2009-2013. Skripsi. Fakultas Ekonomi dan Bisnis Islam. Universitas Islam Negeri Alauddin Makassar.

Masruroh, Ignasius. Analisis Kinerja Keuangan Pada PT PLN (Persero) Distribusi Jawa Barat dan Banten. Jurnal Ekonomi, Manajemen dan Perbankan, Vol. 2 No. 3 Desember 2016, Hal 126-127.

Ningsih. K, Rachim. A, Syafariansyah. R. Analisis Kinerja Keuangan PT. Ace Hardware Indonesia. Jurnal OBOR: Oikonomia Borneo, Vol. 1, No. 1, 2019, Hal 23. 
Abd. Halim, Indria Mayesti, Rika Neldawaty dan Sri Wahyuni, Analisis Kinerja Keuangan Perusahaan Dagang PT. Ace Hardware Indonesia, Tbk Di Bursa Efek Indonesia Periode 2014 - 2019

Prakosa Septyo Dwi. Analisis Laporan Keuangan Dalam Menilai Kinerja Keuangan Perusahaan Publik Industri Sub Sektor Semen di PT. BEI. Jurnal Ilmiah Mahasiswa Universitas Surabaya, Vol. 7, No. 1, 2018, Hal 19.

Prastowo, Dwi. 2015. Analisis Laporan Keuangan Konsep dan Aplikasi. Edisi Ketiga, Sekolah Tinggi Ilmu Manajemen YKPN, Yogyakarta.

Rusnaeni. N, Pengaruh Likuiditas dan Solvabilitas Terhadap Rentabilitas Pada PT. Ace Hardware Indonesia ,Tbk. Jurnal Kreatif: pemasaran, Sumberdaya Manusia dan Keuangan, Vol. 6, No.1, Januari 2018, Hal 96.

Rachim Abdul dan Syafariansyah Rudy, Analisis Kinerja Keuangan PT. Ace Hardware Indonesia,Tbk. Jurnal Ekonomika: Manajemen, Akuntansi, dan Perbankan Syari'ah, Vol. 8, No.2, September 2019, Hal 1.

Rusti'ani M.E, Wiyani N.T. Rasio Keuangan Sebagai Indikator untuk Mengukur Kinerja Keuangan Perusahaan Semen. JurnalAkuntansi, Vol. 17, No. 2, Juli-Desember 2017,Hal 128-130.

Sri Rahayu, 2014. Analisis Pengaruh Biaya Operasional Terhadap Kinerja Keuangan pada PT. PLN (Persero) Wilayah Sulselrabar. Skripsi. Fakultas Ekonomi dan Bisnis Islam. UIN Alauddin Makassar.

Suhendro Dedi. Analisis Penilaian Kinerja Keuangan Perusahaan Menggunakan Rasio Keuangan pad PT. Unilever Indonesia,Tbk yang Terdaftar di Bursa Efek Indonesia (BEI). At-Tawassuth, Vol.III, No.1, 2018, Hal 487-490.

https://www.acehardware.co.id/company diakses tanggal 6 September 2020.

www.idx.com diakses pada tanggal 15 September 2020 . 